\title{
BACKPACKER TOURISM AND CULTURAL HERITAGE TOURISM: WAT THUNG SRI MUANG (UBONRATCHATHANI, THAILAND)
}

\author{
Patlapa Buddalerd \\ Architectural Heritage Management and Tourism (International Program), Graduate School \\ Silpakorn University, Thailand
}

\begin{abstract}
One aspect of backpacker tourism that has not been studied extensively, especially in Thailand, is the role of backpacker tourism in promoting cultural tourism as well as its impact on the integrity of cultural heritage. Ideally, cultural tourism is a type of sustainable tourism, which promotes the welfare of local community and the preservation of local culture. Likewise, the influence of the locals on the backpackers is inevitable, hence, affecting their way of thinking about traditional culture, beliefs, and practices. This study determined the role of backpackers in promoting cultural values, with a focus on Wat Thung Sri Muang Ubonratchathani province (Thailand). Cultural tourism is closely linked with the daily lives of the local people. Cultural properties, such as religious temples, are not merely built heritage objects; they also carry with their tangible and intangible heritage values that are strongly engrained into the lives of the local community. The aim of this study is to assess the role of backpacker tourism in sustaining the cultural heritage attributes of the study area - Wat Thung.

The population of respondents and participants in this study were divided into 3 groups, first is group of local community members, second group of backpacker tourists, and third group of operation/managers and relevant government officials. The members of the local community were residents of Ubonratchathani Province. The study used a combination of qualitative and quantitative research techniques. Data collection involved the use of questionnaire survey instruments containing both close-ended and open-ended questions.
\end{abstract}

Keywords: Backpacker tourism

\section{INTRODUCTION}

Backpacker Tourism is a part of sustainable tourism that tourists call themselves "backpackers". They usually travel with their backpack. This backpacker tourism is a tour with affordable price and a long trip than any other tour. Visitors will gain experiences from tourist attractions, culture and mingle with tourist attractions or work during their trip. Visitors may stay with indigenous people or may stay in the hotel, which focused on the economy in the temple and community.

Backpacker tourism has recently become very popular not only in Thailand but also worldwide. The international growth and development of backpacker tourism has strong implications to local economy and to the integrity of environment in general and to local culture in particular. This rapid development has generated some criticisms because of the potential negative effects, notably on the environment, cultural, economic and social aspects, that are often associated with backpackers' behavior and activities (Ooi \& Lang, 2010).

Within certain tourist destinations, backpacker enclaves have become important arenas for tourists where they can have social and cultural exchanges and identity formation. These enclaves provide economically ideal and homely accommodations that cater to the simple needs of backpackers. Because 
backpackers strive to experience something different and personal during their travel, they often mingle with the locals and their families. Backpacker's enclaves are places where there are close interactions among tourists and local community (Richard \& Wilson, 2008)

However, many backpackers may also be considered "eco-tourists" as they are attracted to ecotourism attractions, even though they do not purposely state it in their tourism plan and objectives. Given that sustainable tourism involves nature-based recreation and leisure, adventure ecotourism or backpacker tourism, especially in remote natural areas, has a key role in influencing, either in positive or negative way, the natural state of heritage attractions as well as the local cultural traditions. m. Many backpackers are interested in local culture including religious place, such as temple, where locals visit to pray or meditate. Thus, backpacker tourism to be considered a form of ecotourism should ensure that backpackers are responsible and aware of the conservation of the environment, cultural heritage, and the wellbeing of the local people (Sicrofit, Alos, \& Shestha, 2003).

\section{Backpacker tourism}

Backpacker tourism is a form of tourism involving a group of travelers known as "backpackers" who are often associated with the backpacks that they carry in their travels. Backpackers constitute a small but significant segment of tourism market. They usually take longer trips than others tourists (Pearce, 1990). Some backpackers are educated, and they travel independently (Hottola, 2008). Backpackers have recreational interests similar to those of many others travelers, but they tend to spend more time within a particular destination and spread their expenditures at various sites that they visit (Markward, 2008), hence, contributing to low economic leakage and higher multiplier effect. Backpacker is known to be selforganized in their prolonged multiple-destination journey with flexible travel itinerary that extends beyond the usually cyclical holiday pattern (Serensen, 2003).

\section{Backpacker Activity}

Backpackers experience more of local culture than other visitors because they spend longer in the country. Backpackers striving to experience something different often end up surrounded by the extended familiarity of home even in the most remote destinations. Backpacking provides more contact with local culture remains strong, indicating that backpackers are able to see themselves as experiencing more local culture primarily in relation to other visitors. (Richards\&Willson, 2008)

According to Loker (1993) Backpacker are often keen to share the local lifestyle and Riley (1988) citing "meeting the people" Loker, Murphy \& Pearce (1995) their recreational activities are likely to focus around nature (such as trekking), culture (village stays and more), or adventure (including river rafting or riding camels). Haigh (1995) adopted backpackers to travel more widely than other tourists, seeking unusual or out of the way locations and/or experiences. (Scheyvens, 2002)

In addition backpackers are looking for authentic and usual travel experiences. (Holding, 2009). They want to be a part of local and global culture. Backpacker, supposedly driven by desire to experience something different from their home environment, often end up surrounded by the extended familiarity of home even in the most remote and exotic destination. Backpackers also end up in fashionable destinations, rather than those places where they might expect to find 'real' local. ( Richard\&Wilson, 2008)

\section{RESEARCH OBJECTIVE}

To assess the role of backpacker tourism in sustaining the cultural heritage attributes of the study area Wat Thung (Ubonratchathani ,Thailand)

\section{RESEARCH METHODOLOGY}

The study used a combination of qualitative and quantitative research techniques. Data collection involved the use of questionnaire survey instruments containing both close-ended and open-ended questions. Secondary data were obtained from published literature and government reports.

\section{DATA COLLECTION}

The population simple divided into 3 groups as followed first is group of local community numbers The members of the local community were residents of Ubonratchathani Province are 400 people, second group of backpacker were comprised of visitors of Wat Thung who had been to the Temple during the study period both Thai and international are 398 tourists . The result of both sizes was gauged using the Taro Yamane formula (Tanaree, 2014) and third group of operation/managers and relevant 
government officials are 17 people consisted of selected tour operation/managers, relevant government officials who were willing to be interviewed and participate in the discussions about management and heritage tourism in the study area.

\section{DATA ANALYSIS}

Both primary and secondary data were statistically analyzed using the SPSS program. The mean or average values were presented in graphs and tables. A SWOT analysis was also performed to determine the strengths, weaknesses, opportunities and threats of backpacker tourism development at Wat Thung. The roles of the public and private sectors well as tourist and locals were also assessed. Data Processing and Research Analysis using both content analysis and descriptive statistic following the chart below.

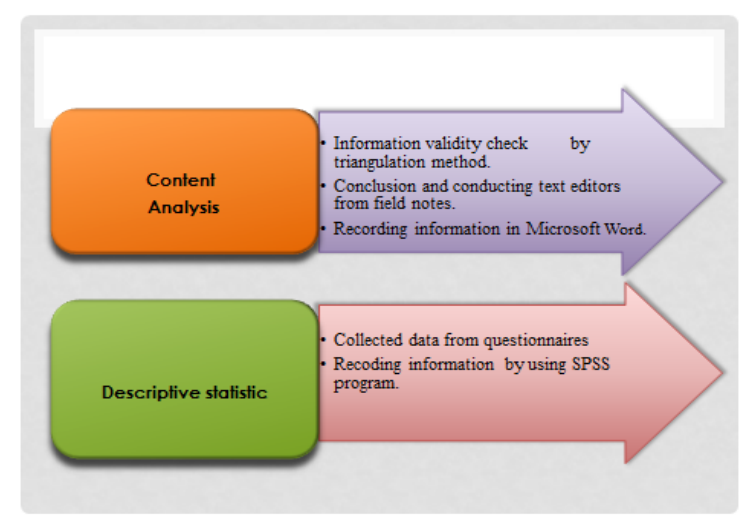

Chart 1: Data Processing and Research Analysis interview guideline.

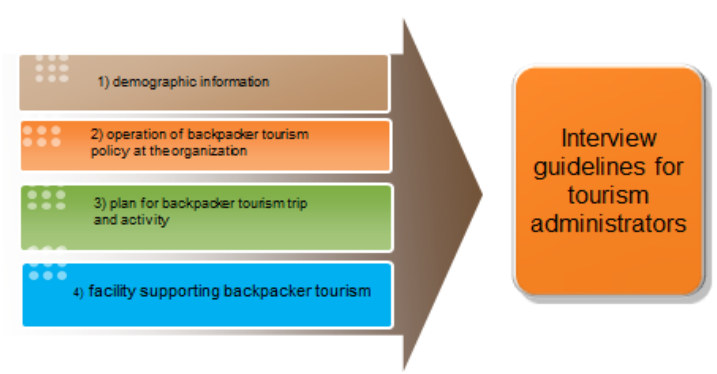

Chart 2: Tourism administrator's tool used

\section{Research tools used descriptive statistic questionnaire with guideline.}

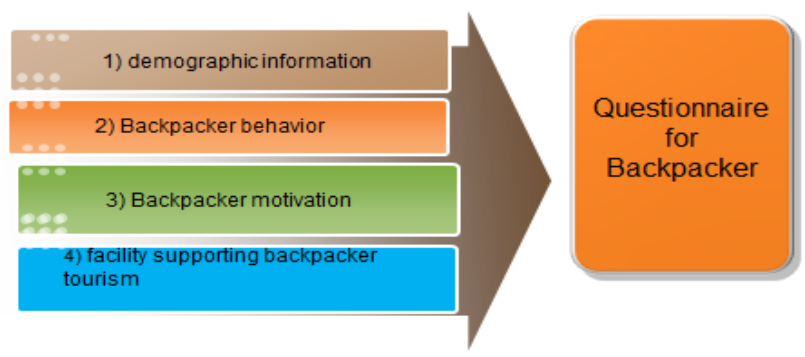

Chart 3: Backpacker tool used

The process is comprised of four major steps, namely, preparation, data collection, collecting primary data, summary of e primary data, and conclusion as shown below.

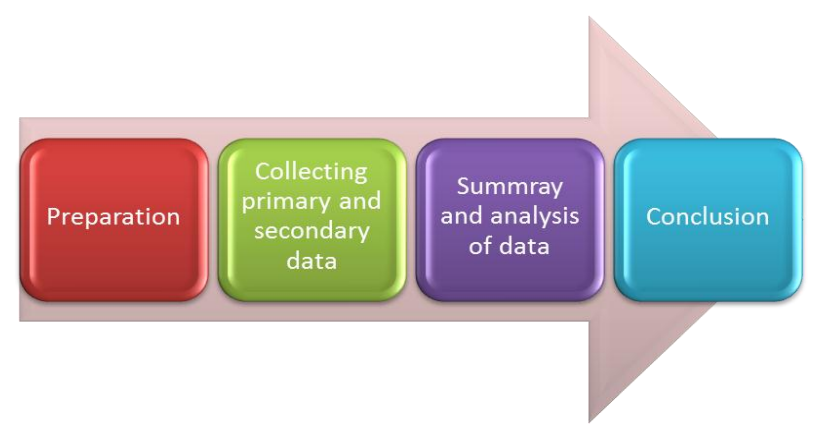

Chart 3: Data collection 


\section{STUDY AREA DESCRIPTION}

\section{Introduction}

In Thailand, religious institutions play an important role to Thai society for a long time from the past to the present. The temple is a center of society which is a place to shape the minds of the public. It includes various activities, culture, architecture, sculpture that have been transferred out by being inspired from the beliefs and ideas of Buddhism as appeared in the various temples.

Wat Thung is the oldest temple in Ubon Ratchathani. Wat Thung plays a key role in various aspects of Ubon Ratchathani from the past to the present. It is the center of the Buddhist community relations activities and events from the past that are important and interesting such as Candle Festival, Bun Mahachat. In addition, the temple is educational and cultural attractions and the other side is Pariyattitham School of the novices from the past to the present. In tourism, the temple is one of the tourist attractions that are supported by public and private sector to promote to be known by several factors, including history, architecture, and accommodation assessment. Transportation is convenient and close to tourist attractions, so it is of interest to tourists and is known for people both in and out of the area.

However, in today's world of communication is convenient and tourists can access tourism information more easily than ever before. Moreover, the transportation is convenient and cheap. Low cost airlines are expansion. As a result, there are more cheap flights. The AEC is coming soon. As a result, tourism has been expanding increasingly. The numbers of tourists who want to travel by themselves are increasing as well. Since they may not be introduced in the tourism, it is easy they may destroy the cultural heritage of those tourist attractions involuntarily. It is therefore essential that each locality should find ways to help those visitors to explore creatively to ensure the sustainability of cultural heritage. Comments and suggestions of all sectors that have progressed to the cultural heritage are necessary to analyze and synthesize to find ways to modify and develop properly and appropriately in the future.

\section{Physical characteristics}

There are several attractions both intangible and intangible heritage at the temple. The main building of Wat Thung faces the east, surrounded by communities, government official building, some other tourist attraction, and Chinese chophouses.

Visitors can enter the temple through three gates located in the north, west, and east. The Temple is
Ubonratchathani, known as the "city of beautiful lotus" is located at the lower region of northeastern part of Thailand along The Mea Moon River. Ubonratchathani is the second biggest city in Thailand and $625 \mathrm{~km}$ away from Bangkok. The province became part of the kingdom of Siam in 1780, during the period of $t$ King Taksin. Ubonratchathani is rich of both natural and cultural heritage. Wat Thung Sri Muang, which is located in the heart of Nai Muang sub district is one of the main travels attractions of the province.

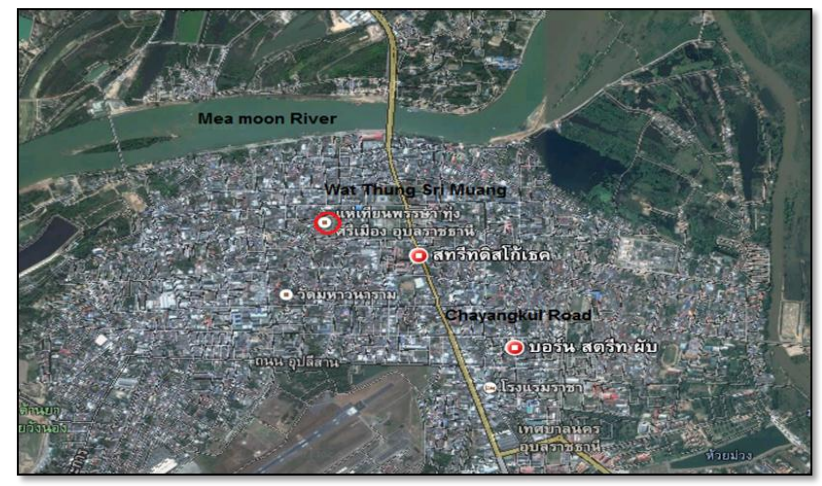

Figure 2: Nai Muang Sub- district map

Source:http://jj5izx.blogspot.com/2013/03/hs25dxthai land-on-20m-cw.html

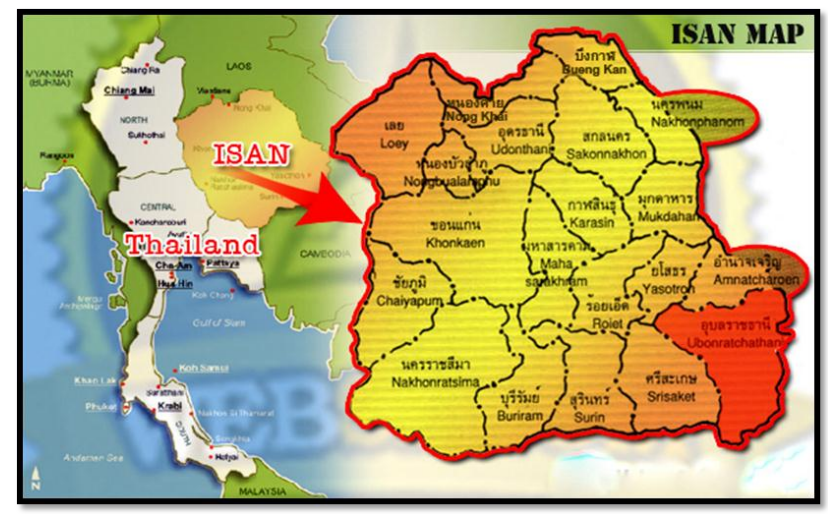

Figure 1: Ubonratchathani

Source: http://jj5izx.blogspot.com/2013/03/hs25dxthailand-on20m-cw.htm

surrounded by the city main streets, such Phalorangrit $\mathrm{Rd}$ to the north, Nakonban $\mathrm{Rd}$ to the west, and Upplalisan $\mathrm{Rd}$. to the east. It is therefore conveniently located and accessible. It is also close to other tourist attractions, as Thung Sri Muang Park, the national museum, Wat Maneewana ram in the north, Wat Pra yai and Mea Moon River. 


\section{Environment inside the temple}

The precinct where the Wat Thing is built is planted to many trees. The temple is divided into three zones; monastic zone, $I$ is Buddhist shrine zone, and crematory zone. The monastic zone is restricted to novices and monks. The Buddhist shrine zone includes the Sermon Hall, Tripataka library Hall, bell tower, visitor center, toilet, multipurpose building, and scripture educating building. Visitors are allowed to go to the consist Buddhist shrine zone. Although they can also visit monastic zone, they first have to ask the permission of the temple manager. The crematory zone consists of crematory and multipurpose building area.

Wat Thung is also known as a school of Barley Sanskrit, where monks and novice study s

\section{Tourist attractions at Wat Thung}

Wat Thung offer very interesting cultural and historical objects and materials that attract many visitors. Two buildings - In addition \the Phrabat hall and Tripataka library hall are listed by the Fine Arts Department as cultural heritage site. The Buddha images, both Pha cha yai Ong Ngen and Phachao Yai Sri Muang, are well known as the province important ancient images. . Recently, a community museum was $\backslash$ opened, and there is no entrance fee.

\section{Phrabat Hall or Buddha footprint hall}

Art characteristic and architecture style of the building is mixed between Thai Siam in period if the King Rama III of Siam and Laos art and architecture style. Subsequently, it heaps up the soils at the courtyard of Phrabat hall to prevent flooding in the rainy season. It is created a dam glass wall, Phrabat hall. There are two layers around Phrabat with $23 \mathrm{~m}$ in width, $32 \mathrm{~m}$ in length and heap up as high as a tower pedestal. It was dug the soils from the north pool(The Tripataka Hall pool) which is $13 \mathrm{~m}$. in width, $24 \mathrm{~m}$. in length and $3 \mathrm{~m}$. in depth. The roof decorating is mixed between both Thai and Laos. Door Panel and window panels were decorated with Thai wooden carving (Period of king Rama III art and Architecture style). The whole building was built with bricks and mortar, covered with plaster and decorated with stucco modeling. Four side of insider building walls were painted murals painting that showed local people along Mea Moon river way of life,

angels, and Buddha. This art style always apparent on Siam king Rama III art characteristic style.

Decorated by using Laos's art and architecture style. The Phrabat hall was listed of the Fine Arts

\section{Tripataka Library Hall (Hor Trai)}

Hor Trai one of the most beautiful buildings in Wat Thung (locally called Hor Trai Krang Nam Wat Thung Sri Muang). It is strongly promoted as the main travel attraction of Ubonratchathani province. The wooden building Istands in the middle of a manmade pond, called Sa Bok Khorani Sri Muang, which is full of colorful lotus plants. The building is considered with unique and outstanding artistic and architectural style. Plenty of visitors around Thailand and oversea have headed to visit the charming Hor Trai each year. (Pha-kru Chandee, 2013)

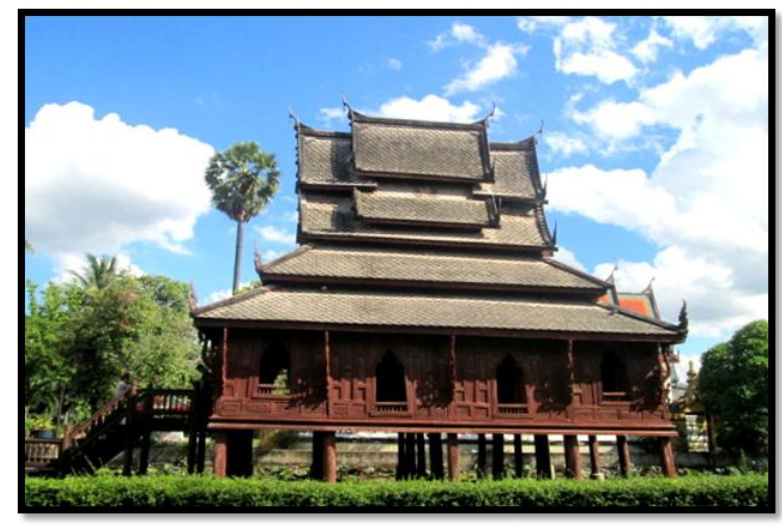

Figure 4: Tripataka Library or Hor Trai Source: Patlapa buddalerd

Department as national historic site in 1985. (Wikipedia,2010)
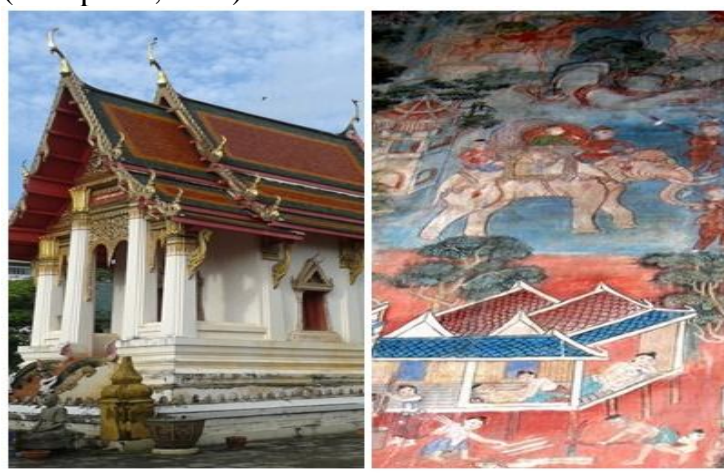

Figure5: Phrabat Hall / moral painting inside the hall Source: Phra-kroo Chandee

Phra Chao Yai Ong Ngen which was enshrined in Phrabath hall.The stature Buddha is an attitude of subduing Mara and covered with gold paint over two hundred years. Later it found out that the body was bronze. So, it is the source of fixing the puzzle what is actually the history. Therefore it is concluded that Phra Chao Yai Ong Ngen is the art of Rattanakosin period in the 24th century. 


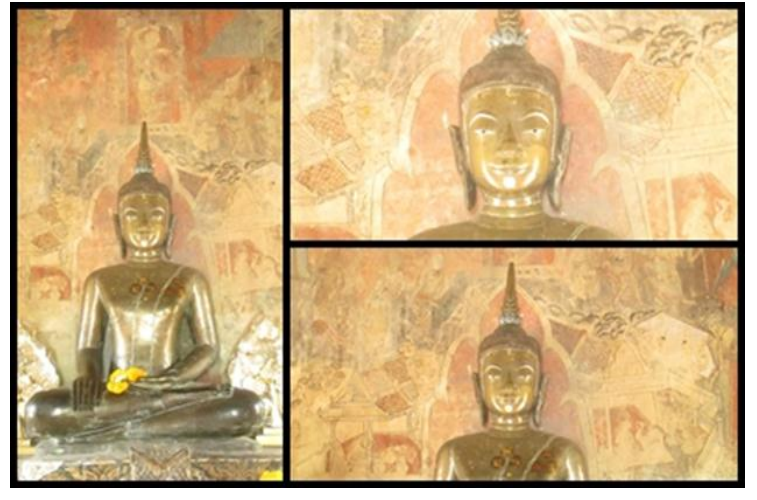

Figure 6 : Phra Chao Yai Ong Ngen

Source: Patlapa buddalerd

\section{Festival and ceremony resource}

Candle festival: Ubonratchathani candle festival is a famous festival in Thailand. The festival will be taking a place at the Thung Sri Muang Park. It is the biggest and most interesting festival in the province. There are a lot of visitors both in Thailand and oversea are headed to joy the festival. There will be traditional dancing parades and candle parades from each community the city and from other district of Ubonratchathani come to joy candle competition in the town too. There are two kind of candle pared that divided by design and decorating first, carving candle second, collage candle. Usually the candle will be decorated on big trailer. The decorating using traditional carver and special technique work on candle. Usually Wat Tung Sri Muang joyed for candle festival contest and won for award on 2007 over participating of local local community, related sectors and opened wild for every visitor. After festival the candle will be present at the temple until next year festival.

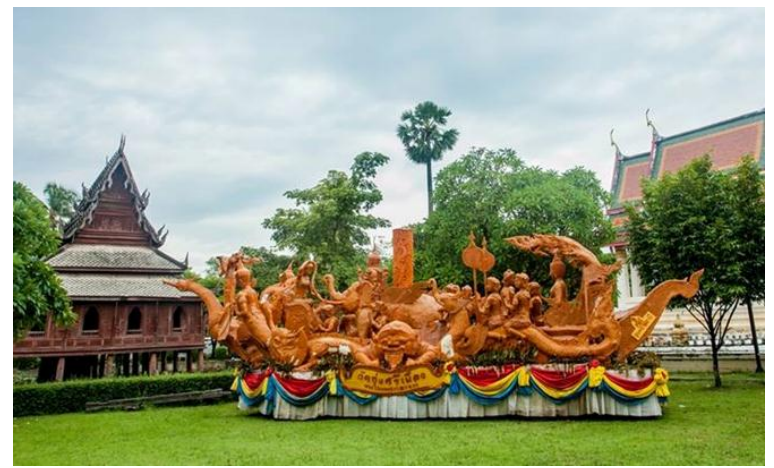

Figure 7: Candle festival

Source: Phra-kroo Chandee

Mahachat Festival - It is called Boon $\mathrm{Pa}$ Wed in native language or Boon Maha Chard in Thai. The temple is held this festival annually during March every year. There are third parties to join such as the municipality and schools. Boon Maha Chard is very popular and important to local people. The event has Thet Mahachat, "Wetsandon Chadok" Sermon Ceremony and festive parades and processions through Ubon city. The elephant joins a parade as well. People, students, and government officials have joined the processions that parade around Ubon city. The monks give a sermon and there is the festival for several consecutive days, where visitors can attend the ceremony.

\section{RESEARCH RESULTS}

Table 1. Travel motivation satisfaction

\begin{tabular}{|l|l|l|l|}
\hline \multirow{2}{*}{ Components } & Item & \multicolumn{2}{|l|}{ Satisfaction } \\
\cline { 2 - 4 } & & SD & Result \\
\hline \multirow{4}{*}{$\begin{array}{l}\text { Attraction at the } \\
\text { temple }\end{array}$} & Phrabath Hall & 0.66 & $\mathrm{G}$ \\
\cline { 2 - 4 } & Tripataka Hall & 0.65 & $\mathrm{G}$ \\
\cline { 2 - 4 } & Phra chayai srimuang Hall & 0.96 & $\mathrm{G}$ \\
\cline { 2 - 4 } & Pracha yai ong ngern & 0.86 & $\mathrm{P}$ \\
\cline { 2 - 4 } & Mural painting & 0.75 & $\mathrm{M}$ \\
\cline { 2 - 4 } & Total & 0.78 & $\mathrm{M}$ \\
\hline \multirow{5}{*}{ Festival } & Candle festival & 0.76 & $\mathrm{M}$ \\
\cline { 2 - 4 } & Fire Floating festival & 1.37 & $\mathrm{P}$ \\
\cline { 2 - 4 } & Maha chart festival & 0.76 & $\mathrm{M}$ \\
\cline { 2 - 4 } & Community relation activity & 0.79 & $\mathrm{M}$ \\
\cline { 2 - 4 } & Total & 0.92 & $\mathrm{G}$ \\
\hline
\end{tabular}




\begin{tabular}{|c|c|c|c|}
\hline \multirow[t]{8}{*}{ Cultural value } & $\begin{array}{l}\text { Be directly or tangibly associated with events or living } \\
\text { traditions, with ideas, or with beliefs, with artistic and literary } \\
\text { works of outstanding universal significance }\end{array}$ & 0.68 & M \\
\hline & $\begin{array}{l}\text { Be outstanding example of a type of building or architectural or } \\
\text { technological ensemble or landscape which illustrates (a) } \\
\text { significant stage(s) in human history }\end{array}$ & 0.78 & M \\
\hline & The building are beautiful & 0.68 & $\mathrm{M}$ \\
\hline & $\begin{array}{l}\text { Be an outstanding example of a traditional human settlement or } \\
\text { land-use which is representative of a culture (or cultures), } \\
\text { especially when it has become vulnerable under the impact of } \\
\text { irreversible change }\end{array}$ & 0.64 & M \\
\hline & $\begin{array}{l}\text { Bear a unique or at least exceptional testimony to a cultural } \\
\text { tradition or to a civilization which is living or which has } \\
\text { disappeared }\end{array}$ & 0.65 & G \\
\hline & Represent a masterpiece of human creative genius & 0.40 & $\mathrm{M}$ \\
\hline & $\begin{array}{l}\text { Exhibit an important interchange of human values over a span of } \\
\text { time or within a cultural area of the world, on developments in } \\
\text { architecture or technology, monumental arts }\end{array}$ & 0.79 & M \\
\hline & Total & 0.65 & $\mathrm{M}$ \\
\hline
\end{tabular}

Table 2. Tourism industry management satisfaction

\begin{tabular}{|c|c|c|c|}
\hline \multirow{24}{*}{ Components } & \multirow[b]{2}{*}{ Item } & \multicolumn{2}{|c|}{ Satisfaction } \\
\hline & & SD & \\
\hline & Tourist control entrance- exit & 0.43 & $\mathrm{P}$ \\
\hline & Providing tourist information & 0.43 & $\mathrm{P}$ \\
\hline & Official advised & 0.46 & $\mathrm{P}$ \\
\hline & Total & 0.44 & $\mathrm{P}$ \\
\hline & Public transportation & 1.38 & $\mathrm{M}$ \\
\hline & Private vehicle & 0.57 & G \\
\hline & Walking & 0.76 & $\mathrm{M}$ \\
\hline & Total & 0.90 & $\mathrm{M}$ \\
\hline & Friendly service and helpful & 0.70 & G \\
\hline & Close to the community & 0.73 & G \\
\hline & Conductive to learn traditional culture & 0.53 & G \\
\hline & Comfortable & 0.56 & G \\
\hline & Total & 0.64 & G \\
\hline & Religious activities out of the temple & 0.91 & G \\
\hline & Religious activities in the temple & 0.60 & G \\
\hline & $\begin{array}{l}\text { Have knowledge by participating and observing while } \\
\text { the trip }\end{array}$ & 0.69 & G \\
\hline & Have more good experience from & 0.72 & $\mathrm{M}$ \\
\hline & Interesting & 0.65 & $\mathrm{M}$ \\
\hline & Advisable to the site & 0.76 & M \\
\hline & Attractiveness & 0.71 & $\mathrm{M}$ \\
\hline & Total & 0.72 & $\mathrm{M}$ \\
\hline & Traffic sign & 0.63 & $\mathrm{P}$ \\
\hline
\end{tabular}




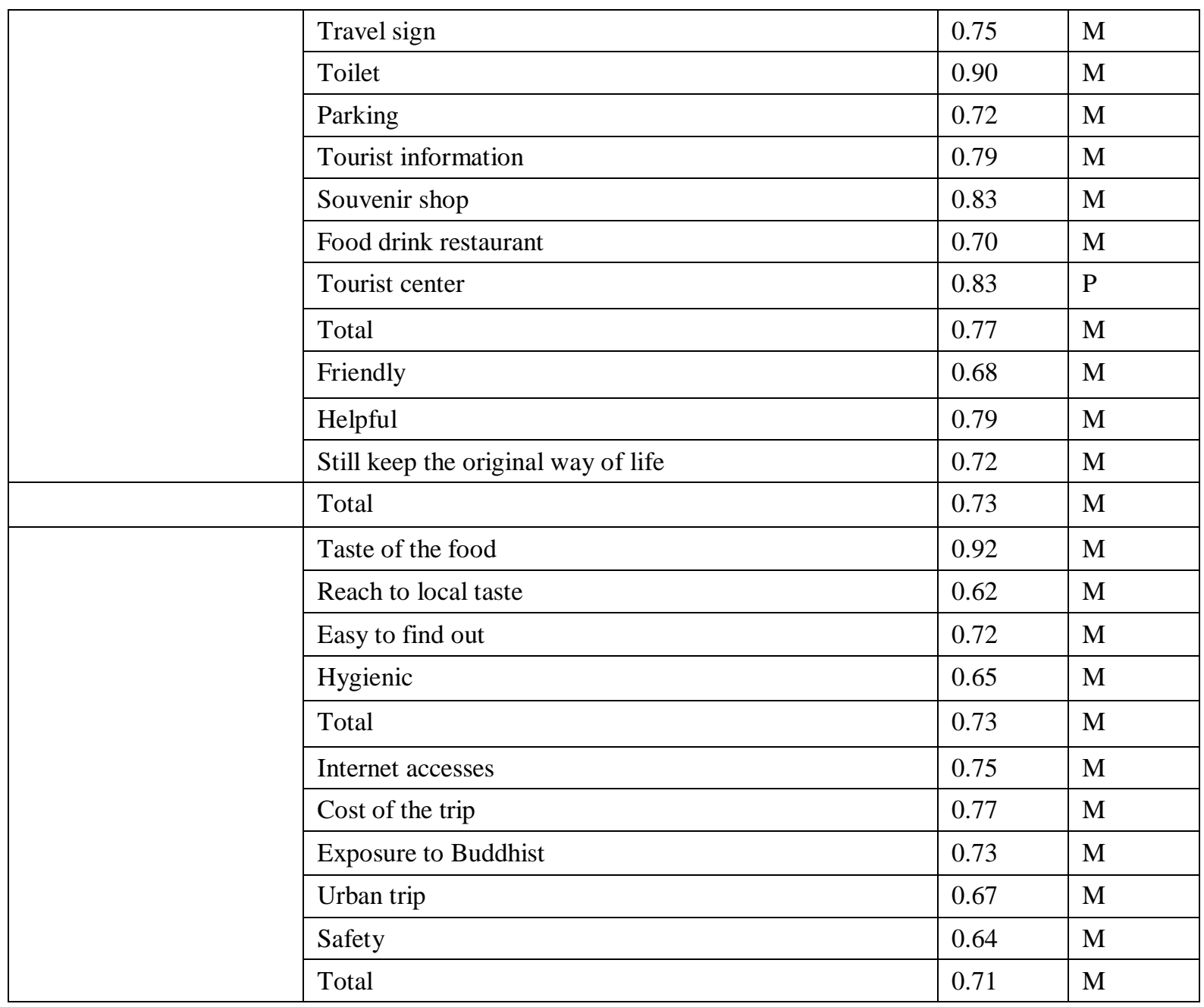

Table 3. Tour operation/managers, relevant government official's suggestion

\begin{tabular}{|c|c|c|c|}
\hline Components & Item & $\mathrm{N}$ & $\%$ \\
\hline & Equip with the entire tourism management. & 3 & 5.00 \\
\hline & Promote community involvement in conservation. & 5 & 9.00 \\
\hline & Arrange guides for tourists. & 3 & 5.00 \\
\hline & Tourist information such as brochures. & 2 & 3.00 \\
\hline & Set the regulations for visiting clearly. & 2 & 3.00 \\
\hline & Promote cultural heritage and value of the temple. & 5 & 9.00 \\
\hline & $\begin{array}{l}\text { Improve the surrounding community to be appropriate. } \\
\text { Harmony with eco-tourism. }\end{array}$ & 1 & 200 \\
\hline & $\begin{array}{l}\text { All sectors involved in the decision, focusing on } \\
\text { cooperation. }\end{array}$ & 8 & 14.00 \\
\hline & Improve landscape to be appropriate. & 1 & 2.00 \\
\hline & $\begin{array}{l}\text { Arrange the temple to be a place of ecotourism and } \\
\text { recreational facility for the community. }\end{array}$ & 1 & 2.00 \\
\hline & Share benefits fairly. & 1 & 2.00 \\
\hline & $\begin{array}{l}\text { Need external organizations to help give knowledge such } \\
\text { as knowledge of welcome tourists activity and language. }\end{array}$ & 6 & 11.00 \\
\hline & Do not try to change things too much. & 2 & 3.00 \\
\hline
\end{tabular}




\begin{tabular}{|c|c|c|c|}
\hline \multirow[t]{12}{*}{ Management } & $\begin{array}{l}\text { Improve things which already have and work well like } \\
\text { existing traditional activity. }\end{array}$ & 3 & 5.00 \\
\hline & Improve access to facilities such as map. & 1 & 2.00 \\
\hline & Find budget support. & 1 & 2.00 \\
\hline & The government has to support. & 3 & 5.00 \\
\hline & Cleanliness & 1 & 2.00 \\
\hline & Networking in tourism. & 1 & 2.00 \\
\hline & Provide direct person responsible for the temple. & 1 & 2.00 \\
\hline & Leaders focus and strengthened. & 1 & 2.00 \\
\hline & Promote homestay accommodation. & 1 & 2.00 \\
\hline & Focus on sufficiently developed. & 1 & 2.00 \\
\hline & Build awareness, cherish the community culture. & 1 & 2.00 \\
\hline & Total & 55 & 100 \\
\hline \multirow{13}{*}{$\begin{array}{l}\text { Instructions to } \\
\text { improve the } \\
\text { backpacker travel } \\
\text { experience }\end{array}$} & Arrange information for tourists. & 3 & 8.00 \\
\hline & Have database about the temple. & 3 & 8.00 \\
\hline & Arrange staff to guide tourists. & 2 & 5.50 \\
\hline & $\begin{array}{l}\text { Educate the local community about local arts and improve } \\
\text { a positive attitude towards tourists. }\end{array}$ & 6 & 17.00 \\
\hline & The local people are involved in tourism activities. & 4 & 11.00 \\
\hline & Set tourist routes to be linked and interesting. & 6 & 17.00 \\
\hline & Try to pull the local outstanding to present. & 2 & 5.50 \\
\hline & The community members are friendly to tourists. & 2 & 5.50 \\
\hline & $\begin{array}{l}\text { Update religious activities and give tourists the } \\
\text { opportunity to participate. }\end{array}$ & 1 & 3.00 \\
\hline & $\begin{array}{l}\text { Improve tourist routes to enter the community more to } \\
\text { increase access to community resources. }\end{array}$ & 4 & 11.00 \\
\hline & Improve the existing activities to more interesting. & 2 & 5.50 \\
\hline & Increase tourism routes. & 1 & 3.00 \\
\hline & Total & 36 & 100 \\
\hline \multirow{12}{*}{$\begin{array}{l}\text { Role of community to } \\
\text { maintain the local } \\
\text { culture integrity }\end{array}$} & $\begin{array}{l}\text { Educate the local people in the arts and culture and proud } \\
\text { of it. }\end{array}$ & 3 & 8.00 \\
\hline & $\begin{array}{l}\text { Provide community involvement in management decisions } \\
\text { and arrange activities. }\end{array}$ & 8 & 20.00 \\
\hline & Create awareness of the arts and culture to the community. & 2 & 5.00 \\
\hline & Raise awareness of the arts and culture to the community. & 8 & 20.00 \\
\hline & Distribute income from tourism to the community. & 4 & 10.00 \\
\hline & The community gives the importance of the temple. & 3 & 7.5 \\
\hline & Create a positive attitude towards backpackers. & 2 & 5.00 \\
\hline & $\begin{array}{l}\text { The community members must act as a conservator and a } \\
\text { good model. }\end{array}$ & 5 & 12.50 \\
\hline & $\begin{array}{l}\text { The community members should not see their personal } \\
\text { benefit. }\end{array}$ & 4 & 10.00 \\
\hline & Transfer knowledge to future generations. & 1 & 2.50 \\
\hline & Total & 40 & 100 \\
\hline & Follow the regulations of the temple and the community. & 11 & 35.00 \\
\hline
\end{tabular}


Role of backpackers to preserve cultural integrity

\begin{tabular}{|l|l|l|}
\hline Accept the local culture. & 10 & 32.00 \\
\hline Studying tourist information before visiting. & 3 & 10.00 \\
\hline Dress appropriately. & 3 & 10.00 \\
\hline Transfer experience to others. & 1 & 3.00 \\
\hline Do not try to change and deviate the local culture. & 3 & 10.00 \\
\hline Total & 31 & 100 \\
\hline
\end{tabular}

Table 4. Stakeholder suggestion

\begin{tabular}{|c|c|c|c|}
\hline Component & Item & $\mathrm{N}$ & $\%$ \\
\hline \multirow{21}{*}{ Backpacker } & Provide more tourist Information. & 52 & 13.30 \\
\hline & Add advertising. & 44 & 11.30 \\
\hline & Improve local themed restaurants. & 12 & 3.10 \\
\hline & Improve parking lot. & 20 & 5.10 \\
\hline & Improve Tripitaka Hall visiting management. & 4 & 1.00 \\
\hline & Provide more promote in any souse. & 12 & 3.10 \\
\hline & The service is not satisfied. & 12 & 3.10 \\
\hline & Inadequate tourist signage. & 24 & 6.00 \\
\hline & Finding more local cooperation and related stake holder. & 12 & 3.10 \\
\hline & Improve quality souvenir product. & 24 & 6.10 \\
\hline & Should link with other related tourist attractions & 24 & 6.10 \\
\hline & Grow more plants and trees around the area. & 20 & 5.10 \\
\hline & Increase more signage and interpretation in English. & 28 & 7.10 \\
\hline & Add the bin and make it align with the tourist attraction. & 23 & 6.00 \\
\hline & $\begin{array}{l}\text { Have a guided tour to provide information to tourists at } \\
\text { tourist attraction }\end{array}$ & 12 & 3.10 \\
\hline & Present about mural paintings. & 4 & 1.00 \\
\hline & Cleanliness. & 20 & 5.10 \\
\hline & Information leaflets to tourists. & 12 & 3.10 \\
\hline & There is lines block tourist area around the pool. & 20 & 5.10 \\
\hline & Local people should blend with the local culture. & 12 & 3.10 \\
\hline & Total & 391 & 100 \\
\hline & Landscape makes a nice visit. & 112 & 14.00 \\
\hline & Signage and map. & 80 & 10.00 \\
\hline & Organize pathway and grow more trees. & 8 & 1.00 \\
\hline & Cleanliness. & 96 & 12.00 \\
\hline & Keep original . & 32 & 4.00 \\
\hline & More PR and presentation. & 56 & 7.00 \\
\hline & $\begin{array}{l}\text { Person responsible, guide and regular staff at the place and } \\
\text { building. }\end{array}$ & 56 & 7.00 \\
\hline & Traffic and parking. & 32 & 4.0 \\
\hline
\end{tabular}




\begin{tabular}{|l|l|l|l|}
\hline \multirow{4}{*}{ Local community } & Safety. & 40 & 5.00 \\
\cline { 2 - 4 } & Toilets. & 28 & 3.50 \\
\cline { 2 - 4 } & Tripitaka Hall with guano. & 16 & 2.00 \\
\cline { 2 - 4 } & Encourage the study of Dhamma. & 8 & 1.00 \\
\cline { 2 - 4 } & Accommodation. & 12 & 1.50 \\
\cline { 2 - 4 } & Add more activity on the merits. & 52 & 6.50 \\
\cline { 2 - 4 } & Provide interpretation on murals. & 64 & 8.0 \\
\cline { 2 - 4 } & Have a tourist center, sarong for rent, and souvenir shop. & 32 & 4.0 \\
\cline { 2 - 4 } & Make fencing look beautiful and attractive. & 20 & 2.51 \\
\cline { 2 - 4 } & People who do not answer this item. & 52 & 6.87 \\
\cline { 2 - 4 } & Total & 796 & 100 \\
\hline
\end{tabular}

\section{CONCLUSION}

The research show that backpacker characteristic, backpacker motivation that provided into two components first, attraction second, festival, Moreover backpacker satisfaction tourism management industry and cultural heritage value, recommendation of both group of government official and non-government official both in and outside Ubonratchathani province including related recommendation of both local communities and backpackers. The results of the research will lead to the backpacker development plan that comply with the National Tourism Development Plan No. 11 (2012-2016) and the needed of all stake holder under the constraints of limited resources for their upmost benefit and sustainable development in the future.

\section{DISCUSSION AND RECOMMENDATION}

Based on the information by previously discussed above, section of the government and entrepreneurs in business should promote backpacker tourism by following strategies plan. The Strategic plan for backpackers and sustainable tourism of Wat Thung, have divided into 4 strategies. First, strategic development of tourism to be suitable and attractive for backpackers, second, strategy to raise awareness on the conservation of cultural heritage, arts, traditions and local wisdom, third, Strategy for stimulating economic equity, forth, strategy to develop community under efficiency economic to promote backpacker tourism.
Strategy 1 Tourism development for attracting backpackers

Tactic 1: To use the temple areas for backpacker tourism and tourism-related

Tactic 2: Environmental management in the temple

Strategy 2 Awareness rising on conservation of cultural heritage, cultural traditions and local wisdom

Tactic 1: To raise awareness.

Tactic 2: To develop the mental maturity.

Tactic 3: To preserve and promote culture for backpacker tourism

\section{Strategy 3 Stimulating local economy}

Tactic 1: To develop souvenirs and tourism products.

Tactic 2: Tourism management

Tactic 3: Marketing management

Strategy 4 Development of community based on sufficiency economy principle for sustainable tourism development

Tactic 1: To strengthen the community.

Tactic 2: To distribution of income to local community.

Tactic 3: To promote local authorities to raise awareness about the importance of the cultural heritage of the locality. 
Tactic 4: To create opportunities for the temple to spread Buddhism into the community and tourists sectors.

\section{ACKNOWLEDGEMENTS}

This research article is part of the research article Backpacker tourism and cultural heritage tourism: Wat Thung Sri Muang (Ubonratchathani, Thailand) the article cannot be completed without a great support of Professor Dr. Corazon Catibog-Sinha. I am using this opportunity. I am thankful for their aspiring guidance, invaluably constructive criticism and friendly advice during the project work. Without her passionate participation and input, the validation survey could not have been successfully conducted.

\section{REFERENCES}

Holding. (2009). Backpacker Tourist Action Plan 2012-2013 Tourism Victoria 2009-

2013. Melbourne, Victoria: The Victoria Government.

Hottola. (2008). Farewell Countercultural wandered Dress and styles in South Asia backpacking. Finish University New work for tourism studies, University of Joensuu, Savonlinna, Finland.

Markward. (2008). Backpacker: The next generation? (Master Thesis).Auckland University, Aukland.

HS25DX (Thailand). (2013), Isan map. Retrieved July

15,2014,fromhttp://jj5izx.blogspot.com/2013/03/hs25 dxthailand-on-20m-cw.html
Ooi, H., \& Lang, H. (2010). Investigating the overlap between backpacker tourism and volunteer tourism motivation of sustainable tourism. Journal of sustainable tourism, 18,191-206.

Pearce. (1990).The backpacker phenomenon: Preliminary answers to basic question. Tourism Western Australia. The government of Western Australia.

(Phra-Kroo Chandee, personal interview, October 15, 2013)

Scheyvens. (2002). Backpacker Tourism And Third World Development. Pergamon, 144-164.

Richard,G., \& Wilson.J. (2008).Suspending Reality: An Expiration of enclaves and the backpacker Experience. Current Issue in Tourism, 11,187-199.

Sicroffit, S., Alos, E., \& Shrestha, R (2003). Independent Backpacker Tourism: Key to sustainable Development in Remote Mountain Destination. Retrieved September 8, 2012, from http://lib.icimod.org/record/11419.

Serensen. (2003). Backpacker Ethnology. Pergamon, 30,847-867.

Wikipedia. (2010), Ho trai, Free cyclopedia. Retrieved Aug 23, 2011, from http://en.wikipedia.org/wiki/Ho_trai

Wittata Tanaree. (13 February 2014). In Slide share. Retrieved 10 May 2016 From Slide share: http://www.slideshare.net/somchithIMMORTALsom paseuth/statistics-sampling 